\title{
Development of Christian Character Teaching Materials In the Implementation of Character Education
}

\author{
${ }^{1}$ Melur Dewi Andriaty Zendrato, ${ }^{2}$ Suharno and ${ }^{3}$ Leo Agung \\ 'UNS Postgraduate Student, ${ }^{2}$ Universitas Sebelas Maret, ${ }^{3}$ Universitas Sebelas Maret \\ ${ }^{1}$ melurdewi@student.uns.ac.id, ${ }^{2}$ suharno.52@gmail.com, ${ }^{3}$ leo.agung56@yahoo.co.id
}

\begin{abstract}
Character education is important to do to create a society that has character and has a good moral life. This is the responsibility of Christian education because they are trusted to educate students to be like Christ. Thomas Lickona stated that to form good character requires moral knowledge, moral feelings, and moral action. Christianity sees students as human beings who have fallen into sin. Character education becomes something that must be done to educate sinful humans to know what is God's will in their lives. The purpose of this research is to analyze the development of teaching materials that can be used in the implementation of character education at the Kalam Kudus Christian Middle School Surakarta. The method used in this paper is based on previous research and qualitative methods. The results of this study indicate that character education will have a greater impact when someone believes in Christ. The Holy Spirit will work a new birth in his life and enable him to have a life that is by God's will. Because of that, it is necessary to compile a Christian Character teaching material that will support the implementation of Christian character education. This teaching material is expected to be able to help students to understand what their life purpose and calling can manifest in their daily lives.
\end{abstract}

Keywords: Character education; Christian Education; Teaching materials

\section{INTRODUCTION}

At present, the crime of children in Indonesia has increased significantly. Based on data reported by the National Commission for Child Protection, it was noted that criminal offenses among children experienced a very rapid increase. The increase in crime occurs every year, from 2011 to the end of 2018, 11,116 children in Indonesia were involved in criminal cases. This increase is evidenced by the surge in the number of children who became perpetrators of crime reaching 695 children in 2011 and 2018 reaching 1,434 children [1].

The same thing is also found in children who attend the Kalam Kudus Christian Middle School, Surakarta. Based on an interview conducted on November 23, 2018, with Mr. Felixtian Teknowijoyo as the school principal, there were cases of children bullied by their friends and even some who did physical violence. Also, in interacting on social media, children often use impolite and rude sentences. In teacher meetings with parents, parents often complain about the child's attitude which is getting bolder to resist and violate the parents' orders. Several times children must be called and invited to talk to improve their attitudes and behavior. 
Schools need to perform a comprehensive role, namely to educate children cognitively, affective and psychomotor. Schools need to provide adequate knowledge to students, but not only that, but schools also need to help students to have a good character so that they can have good knowledge and can use this knowledge for useful things [2].

Christian schools exist by centering on God and based on Bible truth. Thus Christian schools have a clear purpose, that is, goals that are based on what is in the Bible. Christian schools aim to educate children so that they can glorify God, tell about God to the world and have grown in knowledge and action. Grow to be like Christ is the goal of Christian education so that education should not be restricted to the knowledge of how this life but it should be up to how to live in $[3]$.

In the research conducted by Sidjabat [4] concluded how important is character education in Christian Schools. The purpose of Christian religious education in schools is to provide knowledge to students to know Jesus as Lord and Savior, while in learning Christianity is directed to the formation of spirituality and character growth. So in this case, moral and character education is inseparable from the formation of spirituality which is a unity in the teaching material of Christian Religious Education.

Lickona in his book Raising Good Children [5] states that the characters contain three interrelated parts namely moral knowledge, moral feelings, and moral actions. Good character consists of knowing good, wanting good and doing good. That means, having habits in the mind, habits in the heart and habits in action. These three things are important to lead a moral life and even moral maturity.

Christian character education is closely related to the understanding of students as disciples of Christ. Graham [6] explains the understanding of students including: first, humans are created in the image and likeness of God; second, humans have been separated from God because of Adam's sin; and third, God works through Jesus Christ to redeem His people from their fall. Character education will run effectively when educators realize the nature of students. They are the image and likeness of God who has fallen into sin and needs salvation in Jesus Christ. The life that has received salvation is finally touched and changed by the Holy Spirit. After they receive Christ, they need an education that helps them grow in the process of maturing to be like Christ.

These students must be educated to mature in Christ so that they will reflect the character of Christ in their lives. Students who have believed in Jesus Christ and experienced a new birth through the work of the Holy Spirit need an education that will enable them to reflect the character of God in their lives. That's why we need a teaching material based on Christ's character to help students have the good character God wants. This emphasizes the importance of teaching materials for character education based on Christian Character. Teaching materials are useful for helping students understand what is meant by good character and can apply them in everyday life. The application of good character must be done with understanding in the classroom and habituation in daily life.

\section{METHOD}

The research method used in this article is based on previous research and qualitative methods [7] Data obtained from various sources relevant to the variables studied. Data collection techniques are done by conducting interviews and observations. Data validity techniques in library research carried out with triangulation and a more thorough examination. Data analysis techniques are adjusted to the characteristics of the data obtained by researchers, and qualitative data will be analyzed systematically using qualitative descriptive 
techniques. Qualitative data are analyzed in a systematic, orderly, and structured manner so that the meaning of each stage in the descriptive analysis includes: data collection, data reduction, data display, and verification or conclusion drawing.

Study excavations and explorations were conducted to gather in-depth information about 1) the implementation of character education in the Kalam Kudus Christian Middle School; 2) teaching materials used in the implementation of character education. The subjects of this study were: 1) 8th-grade students at Kalam Kudus Christian Middle School Surakarta; 2) character education teachers at the Kalam Kudus Christian Middle School Surakarta.

\section{RESULT AND DISCUSSION}

Character education is an important thing to do because it is the basis in all aspects of students' education. That is the concern of Kalam Kudus Christian Middle School so that they seriously consider the implementation of character education in this school. Kalam Kudus Christian Middle School provides a special time to provide character education. The minimal completeness criteria value of this character lesson is 75 . However, based on an interview conducted on April 13, 2019, with Mr. Joyke as a character lesson teacher, there are still many students who have not yet achieved the minimal completeness criteria value from learning this character. From the recap of the average grade of VIII students, amounting to 193 people, who passed the minimal completeness criteria score was $76 \%$.

In addition to the written values, in daily observations, it can be seen that an understanding of good character has not been demonstrated in the daily lives of students. What is taught in the classroom has not materialized in the actions and behavior of students in activities carried out at school. Based on observations made, one of the obstacles is that the teaching materials used by teachers have not been maximized. Students feel bored using existing teaching materials and do not support for students wanting to have a better character.

Kalam Kudus Christian Middle School has given enough attention to character education. Character education is carried out through morning musings which are followed by all teachers and students. Morning devotional uses a material that explains the characteristics that must be possessed by all teachers and students at school. Also in the implementation of learning, character content has been included in the syllabus and plan for the implementation of learning. Schools also have a special time to convey character education in instructional hours.

But the implementation of character education so far has not been maximized. The teachers deliver character education based on the characters that have been mutually agreed upon to be conveyed. In addition to the written values, in daily observations, it can be seen that an understanding of good character has not been demonstrated in the daily lives of students. What is taught in the classroom has not materialized in the actions and behavior of students in activities carried out at school. Based on observations made, one of the obstacles is that the teaching materials used by teachers have not been maximized. Students feel bored using existing teaching materials and do not support for students wanting to have a better character. However, based on the questionnaire distributed to students, it was found that the character education teaching materials that had been used had not met students' needs. From some questions given to 1938 th grade students of SMP, the following data were found:

$31 \%$ stated that character learning so far did not increase their interest in learning.

$11 \%$ of students stated that character education teaching materials had not been well understood. 
$35 \%$ of students stated that character education teaching materials were not interesting to learn.

$31 \%$ of students stated that the character education he had been attending had not helped him to have a better character.

This situation shows the importance of making teaching materials to support the implementation of character education in Kalam Kudus Christian Middle School. Teaching materials are useful for helping students understand what is meant by good character and can apply them in everyday life. The application of good character must be done with understanding in the classroom and habituation in daily life.

Teaching materials are all forms of material used to help teachers and students in learning and teaching activities. Teaching materials can be either written or unwritten material. Teaching material contains a set of material that is arranged systematically both written and unwritten so that it can create an environment and atmosphere that allows students to learn. Teaching materials are information, tools, and texts needed by the teacher/instructor for planning and studying the implementation of learning [8]

Research conducted by Buchory MS and Tulus Budi Swadayani [9] found that character education can be done by integrating character values in all subjects. In this case, several subjects are closely related to the implementation of character education, such as subjects: (1) Civics, (2) Religious Education, and (3) Sports. This is also done by the Kalam Kudus Surakarta Christian Middle School, which is by integrating the characters in the given subjects. But more than that, this school also gives time devoted to teaching character education.

This is in line with the policies taken by the government. Character education receives special attention from the government. Character Education Reinforcement, in general, is done by integrating Character Education Reinforcement into existing subjects (integrated with the curriculum). However, schools can also teach Character Education Reinforcement values through special subjects that focus on the theme of certain values. The school designs special subjects with specific time allocations provided as part of the formation of students' character. Themes that contain the main values of Character Education Reinforcement are taught in the form of classroom learning with harmonized learning methods so that they can further enrich the practice of Character Education Reinforcement in schools. The themes taken are adapted to the vision and mission of the school. The education unit designs its theme and priority values for what character education they will emphasize and provides specific teachers or empowers existing teachers to teach material about certain values to strengthen character education [10]

Lickona [5] states that character contains three interrelated parts namely moral knowledge, moral feelings, and moral actions. Good character consists of knowing good, wanting good and doing good. That means, having habits in the mind, habits in the heart and habits in action. These three things are important to lead a moral life and even moral maturity. 


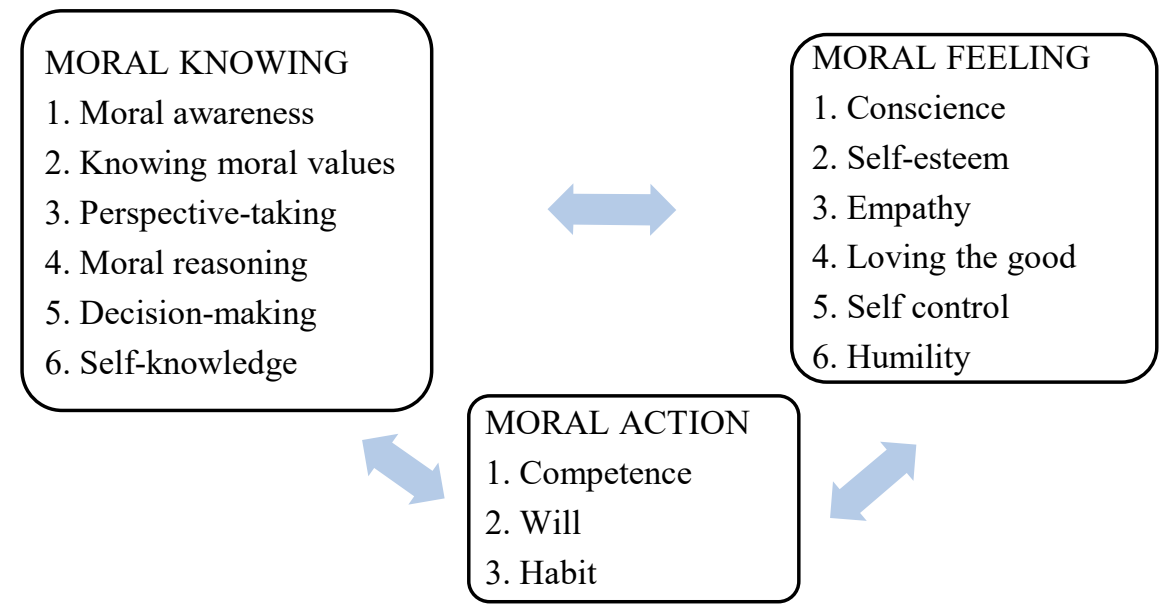

Figure 1. Component Of Good Character

Understanding the importance of knowledge of good things, so that they can be realized in wanting and doing good, encourages schools to develop the right material for use in character education. Muhamad Fauzan Muttaqin, Tri Joko Raharjo and Masturi [11] explained in their research that one of the values that must be instilled in character education is the value of religiosity. These values of religiosity will later become the basis for the implementation of character education in schools. This is also the rationale for the Kalam Kudus Christian Middle School so it is necessary to develop character education materials based on Christian Character.

Christian character education bases its understanding of the Bible. The Bible is an essential source for understanding Christian uniqueness in education. All thoughts and practices of Christian education must be led by the truth of God's revelation when they try to obey Christ in carrying out the process [12]. The Bible is a revelation of God through which humans can know God and His will. The main reason that influences why the Bible is the basis of Christian education is the affirmation of revelation and inspiration in the Bible. The Bible is a special revelation from God in the written form inspired by God (2 Tim. 3:16). The Bible has the authority which is the standard of God's truth and His plan (John 17:17). The Bible also provides an essential resource for salvation (Acts 4: 10-12) and reveals God's real desires to humans (Matt. 4: 4) [13]

Christianity understands that character grows in grace, becoming a response to God's call to humans to "Change in a renewal of the mind." Character is formed through the learning process. Christian learning theory emphasizes the need to acquire knowledge that results in obedience to the Bible which is the word of God. The main goal of learning is to bring students to the right relationship with God based on His word [14] . Character education teaching materials are based on the character of Christ. Sadadohape Matondang [15] in the study who did mention that the character of Christian teens can grow well when imitating Christ as Lord in life. Teaching material based on the character of Christ will help the students have a good character suit God intended. To form this, teaching materials are needed that can support the implementation of character education to the desired results. Appropriate teaching materials will help students to develop true character [16]. 


\section{CONCLUSION}

Based on the results of research that has been done before, it can be concluded that the character education carried out at the Kalam Kudus Christian Middle School Surakarta has not been maximized. That is because teaching materials used by teachers do not yet support to help students have the desire to grow in good character. Because it is necessary to make teaching materials that are based on the Bible, interesting and can be applied in the daily lives of students. Suggestions for other studies are that the character themes to be taught are adjusted to the needs and development of students.

\section{REFERENCES}

[1] T. Tito, "KPAI : Anak Pelaku Kejahatan Meningkat Tiap Tahun - BREAKING NEWS.” [Online]. Available: https://breakingnews.co.id/read/kpai-anak-pelakukejahatan-meningkat-tiap-tahun. [Accessed: 02-Jan-2020].

[2] A. Adams, "the Need for Character Education,” Int. J. Soc. Sci. Humanit. Stud., vol. 3, no. 2, pp. 23-32, 2011 .

[3] P. A. Kienel, The Philosopy of Christian School Education. California: International Association of Christian Schools., 1978.

[4] B. S. Sidjabat and P. Budaya, "PENGUATAN GURU PAK UNTUK PENDIDIKAN KARAKTER :," vol. 3, pp. 30-48, 2019.

[5] T. Lickona, Raising Good Raising Good Children: From Birth Through the Teenage Years. New York: Bantam Books, 2004.

[6] D. L. Graham, Redemptively Teaching. Colorado Springs: ACSI, 2003.

[7] H. Mohajan and H. K. Mohajan, "M P RA Munich Personal RePEc Archive Qualitative Research Methodology in Social Sciences and Related Subjects Qualitative Research Methodology in Social Sciences and Related Subjects," UTC J. Econ. Dev. Environ. People, vol. 85654, no. 85654, p. 1, 2018.

[8] A. Prastowo, Creative Guide to Making Innovative Teaching Materials. Yogyakarta: Diva Press, 2012.

[9] B. MS and T. B. Swadayani, "Implementasi Program Pendidikan Karakter Di SMP," J. Pendidik. Karakter, no. 3, pp. 235-244, 2014.

[10] A. Budhima, "Konsep dan Pedoman Penguatan Pendidikan Karakter," Pus. Anal. dan Singkronisasi Kebijak. Sekertariat Jenderal Kementrian Pendidik. dan Kebud., 2017.

[11] M. F. Muttaqin and T. J. Raharjo, "The Implementation Main Values of Character Education Reinforcement in Elementary School,” J. Prim. Educ., vol. 7, no. 1, pp. 103 $112,2018$.

[12] R. Pazmino, Fondasi Pendidikan Kristen. Bandung: STTB, 2012.

[13] K. Issler, Theological Foundations of Christian Education. Grand Rapids: Baker, 2001.

[14] B. Bode, "Learning Nature" in the Basics of Christian School Education. Surabaya: ACSI, 2012.

[15] S. Matondang, "Memahami Identitas Diri Remaja dalam Kristus Menurut Efesus 2 : 110," vol. 1, no. 1, pp. 105-124, 2018.

[16] K. Saddhono, I. K. Sudarsana, and A. Iskandar, "Implementation of Indonesian Language The learning Based on Information and Communication Technology in Improving Senior High School Students' Achievement in Surakarta," in Journal of Physics: Conference Series, 2019, vol. 1254, no. 1, p. 12059. 
